\title{
SHORT COMMUNICATION \\ Nitrogen uptake by ryegrass from organic wastes applied to a sandy loam soil
}

\author{
C. M. d. S. Cordovil ${ }^{1}$, F. Cabral ${ }^{1}$, J. Coutinho ${ }^{2}$ \& M. J. Goss ${ }^{3}$ \\ ${ }^{1}$ Agricultural and Environmental Chemistry Department, Instituto Superior de Agronomia, Tapada da Ajuda, 1349-017 Lisboa, \\ Portugal, ${ }^{2}$ Universidade de Trás-os-Montes, Soil Science Department-CECEA, ap. 1013, 5000-911 Vila Real, Portugal, and \\ ${ }^{3}$ Kemptville College, University of Guelph, Guelph, ON, Canada K0G $1 \mathrm{JO}$
}

\begin{abstract}
Sandy-textured Mediterranean soils are invariably depleted in organic matter and supply only small amounts of $\mathrm{N}$ to crops. To compensate for these deficiencies, we tested the $\mathrm{N}$ supply from six organic wastes applied to a Cambic Arenosol in pots growing ryegrass. The results showed that the behaviour of the wastes in supplying $\mathrm{N}$ to a ryegrass crop grown in this soil can be predicted by observing their performance in laboratory aerobic incubations. The $\mathrm{N}$ made available during these incubations fitted well to a one-pool kinetic model.
\end{abstract}

Keywords: Nitrogen mineralization, organic wastes, ryegrass, sandy loam texture

\section{Introduction}

Soil conservation implies not only the application of sound management practices to prevent the loss of good land, but also the efficient recycling of organic materials produced by different activities. These are manures and byproducts from industry and municipal wastes. Such wastes cannot only be recycled as a source of plant nutrients, but can also enhance future crop production by improving soil quality (Vagstad et al., 2001; Douglas et al., 2003). By adding organic wastes to the soil, total nitrogen $(\mathrm{N})$, organic matter, microbial population, enzyme activity, moisture retention, $\mathrm{pH}$ buffering capacity and crop yields can be increased (Cordovil, 2004).

Nitrogen is often a limiting factor in the growth of many forage species such as ryegrass. Moreover, crops grown on coarser textured soils may require more $\mathrm{N}$ fertilizer because lesser amounts will be mineralized from the relatively small organic matter content.

The objective of the present study was to evaluate results previously obtained in laboratory aerobic incubation experiments (Cordovil et al., 2005) by assessing $\mathrm{N}$ mineralization of six wastes from different sources (animal, industrial and urban) using $\mathrm{N}$ uptake by ryegrass plants as a measure of

Correspondence: C. M. d. S. Cordovil.

E-mail: cmscordovil@isa.utl.pt

Received October 2005; accepted after revision February 2006 their net mineralization and determining how far the supply of organic $\mathrm{N}$ in sandy soils may contribute to plant available $\mathrm{N}$ for ryegrass.

\section{Materials and methods}

Six organic wastes previously dried and sieved were mixed separately with loamy sand soil (Cambic Arenosol) with $0.34 \mathrm{~g} \mathrm{~kg}^{-1}$ total Kjeldahl-N and $5.9 \mathrm{~g} \mathrm{~kg}^{-1} \mathrm{OM}$ : composted solid municipal waste, secondary pulp mill sludge, horn meal, poultry manure, dried solid phase from pig slurry and composted pig manure. The wastes were characterized by $\mathrm{OM}$ and Kjeldahl-N contents and the $\mathrm{C} / \mathrm{N}$ ratio (Table 1) (Cordovil et al., 2005). Ryegrass (Lolium perenne L. cv. Billion) was grown for nearly 6 months, in KickBrauchmann pots under controlled environment conditions, and cut five times.

Two rates of the wastes, corresponding to 80 and $160 \mathrm{~kg}$ total $\mathrm{N} \mathrm{ha}^{-1}$, were tested. Half of the pots received the equivalent to $120 \mathrm{~kg}$ mineral $\mathrm{N} \mathrm{ha}^{-1}$. The remaining pots received only waste as $\mathrm{N}$ supply. The control treatment received the same mineral $\mathrm{N}$ fertilization and no organic amendment. Pots were weighed and watered every 2 days to maintain soil at $60 \%$ field capacity. Plant herbage was harvested and analysed for $\mathrm{N}$ content. Data was statistically analysed and correlated with previous incubation results (Cordovil et al., 2005). 
Table 1 Chemical characteristics of the six organic wastes under study

\begin{tabular}{lccccc}
\hline & $\begin{array}{c}\text { Composted solid } \\
\text { municipal waste }\end{array}$ & $\begin{array}{c}\text { Secondary } \\
\text { sludge }\end{array}$ & $\begin{array}{c}\text { Horn } \\
\text { meal }\end{array}$ & $\begin{array}{c}\text { Poultry } \\
\text { manure }\end{array}$ & $\begin{array}{c}\text { Solid phase } \\
\text { from pig slurry } \\
\text { pig manure }\end{array}$ \\
\hline $\mathrm{N}_{\mathrm{kj}}\left(\mathrm{g} \mathrm{kg}^{-1}\right)$ & 17.8 & 42.4 & 116.7 & 35.5 & 17.4 \\
$\mathrm{OM}\left(\mathrm{g} \mathrm{kg}^{-1}\right)$ & 482 & 875 & 845 & 766 & 714 \\
$\mathrm{C} / \mathrm{N}$ & 15.7 & 12.7 & 4.2 & 12.5 & 21.7 \\
\hline
\end{tabular}

$\mathrm{N}_{\mathrm{kj}}$, kjeldahl nitrogen; OM, organic matter; $\mathrm{C} / \mathrm{N}, \mathrm{C}$-to-N ratio.

Table 2 Ryegrass total dry matter production and plant $\mathrm{N}$ uptake

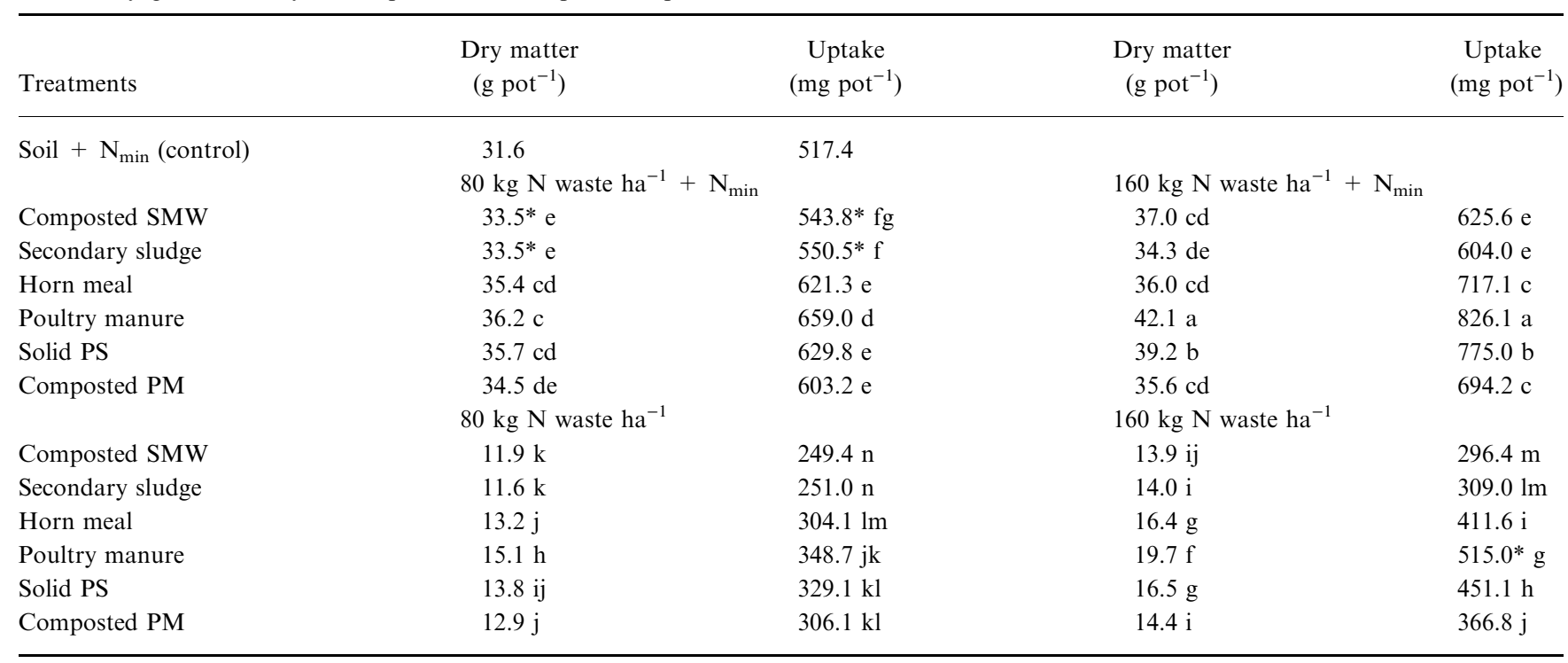

*Not significantly different from control (according to Dunnett test) $(P<0.05)$. Values of the same column followed by the same letter are not significantly different according to LSD test $(P<0.05)$. For key to wastes see Table $1 . \mathrm{N}_{\min }=120 \mathrm{~kg} \mathrm{ha}^{-1}$ fertilizer N.

\section{Results and discussion}

All treatments without the addition of mineral nitrogen fertilizer resulted in less plant growth, as well as less $\mathrm{N}$ uptake by the plants, when compared with that of the control (Table 2). Biomass production was well correlated with $\mathrm{N}$ uptake by ryegrass $(0.99<r<1.00)$, reflecting growth being dependent on $\mathrm{N}$ supply to the crop. The greater production from $\mathrm{N}_{\min }$ treatments was probably the result of a greater uptake of $\mathrm{N}$ and of other plant nutrients such as phosphorus and potassium, being stimulated by mineral $\mathrm{N}$ fertilizer application (Evers, 2002; Ehlers \& Goss, 2003), together with a priming effect on mineralization. The priming effect is commonly observed with some organic wastes (Laura, 1975). Poultry manure gave the greatest dry matter production and uptake, followed by the dried solid phase from pig slurry and horn meal, which were not statistically different. The wastes that were less efficient in supporting plant nutrition were the composted municipal solid waste and pulp mill sludge, both with high proportions of recalcitrant $\mathrm{N}$ compounds (Cordovil et al., 2005).

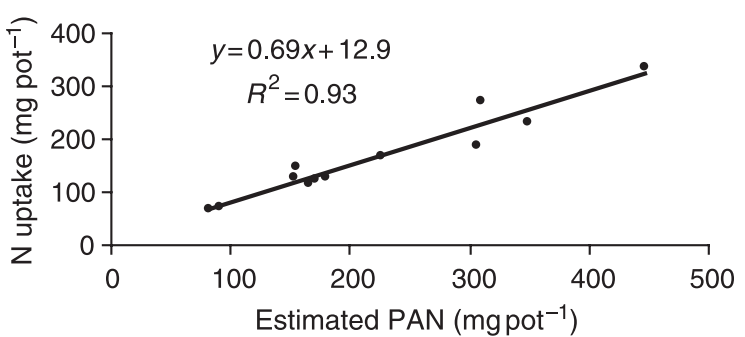

Figure 1 Relationship between the amount of potentially available $\mathrm{N}$ per pot, estimated by the Stanford and Smith model (Cordovil et al., 2005), and $\mathrm{N}$ uptake by ryegrass (all the 12 treatments without mineral $\mathrm{N}$ application).

Results obtained were compared with those obtained in a laboratory aerobic incubation (Figure 1) (Cordovil et al., 2005). Through the fitting of the Stanford \& Smith's (1972) one-pool kinetic model, it was possible to predict the amounts of $\mathrm{N}$ mineralized from each waste tested (Table 3), which followed the sequence: composted solid municipal waste $<$ pulp mill sludge $<$ composted pig manure $<$ solid 


\begin{tabular}{lccccc}
\hline & $\begin{array}{c}\text { Treat 80 } \\
\left(\mathrm{kg} \mathrm{ha}^{-1}\right)\end{array}$ & $\begin{array}{c}\text { Treat 160 } \\
\left(\mathrm{kg} \mathrm{ha}^{-1}\right)\end{array}$ & $\% \mathrm{~N}_{\mathrm{m}}^{\mathrm{a}}$ & $\begin{array}{c}\% \mathrm{~N}_{\mathrm{U}}^{\mathrm{b}} \\
(\mathrm{OW})\end{array}$ & $\begin{array}{c}\% \mathrm{~N}_{\mathrm{U}}^{\mathrm{b}} \\
\left(\mathrm{OW}+\mathrm{N}_{\text {min }}\right)\end{array}$ \\
\hline Composted SMW & 16.9 & 33.9 & 21.3 & 19.3 & 12.2 \\
Pulp mill sludge & 19.3 & 38.6 & 25.2 & 20.5 & 11.6 \\
Horn meal & 25.7 & 51.3 & 32.5 & 36.4 & 30.9 \\
Poultry manure & 29.6 & 59.3 & 36.9 & 50.9 & 44.8 \\
Solid PS & 20.6 & 41.4 & 25.9 & 43.1 & 36.4 \\
Composted PM & 20.1 & 40.2 & 25.0 & 33.3 & 26.4 \\
\hline
\end{tabular}

Table 3. Prediction of mineral $\mathrm{N}$ from organic waste mineralisation at the end of the experiment $\left(\% \mathrm{~N}_{\mathrm{m}}\right)$, according to Stanford \& Smith's (1972) model (except for solid PS to which $\mathrm{N}_{0}{ }^{\mathrm{c}}$ is considered), and $\mathrm{N}$ uptake as percentage of total $\mathrm{N}$ applied in each treatment $\left(\% \mathrm{~N}_{\mathrm{U}}\right)$.

${ }^{\mathrm{a}_{\%}} \mathrm{~N}_{\mathrm{m}}=[(\mathrm{Nm} /$ total $\mathrm{N}$ applied $) \times 100] .{ }^{\mathrm{b}} \mathrm{N}_{\mathrm{U}}=\mathrm{N}$ uptake $(\%$ of total $\mathrm{N}$ applied $) .{ }^{\mathrm{c}} \mathrm{N}_{0}=$ potentially mineralizable N. For key to wastes see Table 1.

phase from pig slurry $<$ horn meal $<$ poultry manure, as reported before by Cordovil et al. (2005).

Results obtained in the present study suggest that the behaviour of the six wastes tested in supplying $\mathrm{N}$ to ryegrass growing in a sandy soil can be predicted by observing their performance in aerobic incubations, because data from these incubations fitted well to Stanford \& Smith's (1972) one-pool kinetic model.

\section{Acknowledgements}

The authors thank the Science and Technology Foundation for financial support and Mrs Isabel Carvalho and Mrs Paula Gonçalves for technical assistance.

\section{References}

Cordovil, C.M.d.S. 2004. Dinâmica do azoto na reciclagem de resíduos orgânicos aplicados ao solo (ed.). Instituto do Ambiente, Lisboa, Portugal.
Cordovil, C.M.d.S., Coutinho, J., Goss, M. \& Cabral, F. 2005. Potentially mineralisable nitrogen from organic materials applied to a sandy soil: fitting the one-pool exponential model. Soil Use and Management, 21, 65-72.

Douglas, J.T., Aitken, M.N. \& Smith, C.A. 2003. Effects of five non-agricultural organic wastes on soil composition and on the yield and nitrogen recovery of Italian ryegrass. Soil Use and Management, 19, 135-138.

Ehlers, W. \& Goss, M.J. 2003. Water Dynamics in Plant Production. CABI Publishing, Wallinford, England.

Evers, G.W. 2002. Ryegrass-bermudagrass production and nutrient uptake when combining nitrogen fertilizer with broiler litter. Agronomy Journal, 94, 905-910.

Laura, R.D. 1975. On the 'priming effect' of organic materials. Soil Science Society of America Proceedings, 39, 807-808.

Stanford, G. \& Smith, S.J. 1972. Nitrogen mineralisation potential of soils. Soil Science Society of America Proceedings, 109, 190-196.

Vagstad, N., Broch-Due, A. \& Lyngstad, I. 2001. Direct and residual effects of pulp and paper mill sludge on crop yield and soil mineral N. Soil Use and Management, 17, 173-178. 